\title{
Re: Thinking Europe
}

\section{Thoughts on Europe:}

Past, Present and Future

Mathieu Segers

Yoeri Albrecht (Eds.)

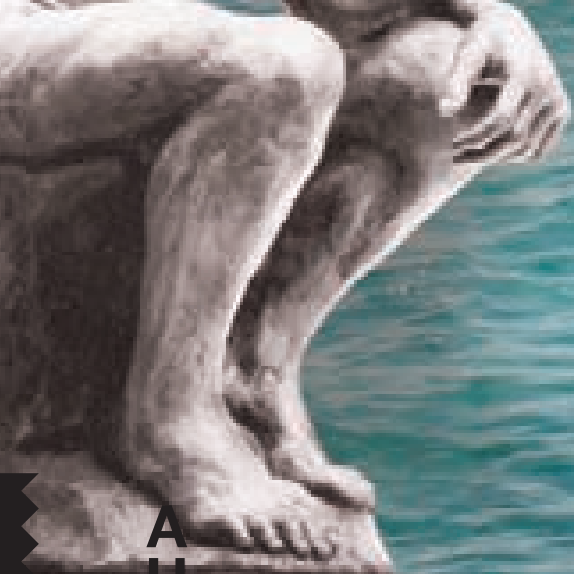

$4 x^{2}+x^{2}$ 
Re:Thinking Europe 



\section{Re:Thinking Europe}

Thoughts on Europe: Past, Present and Future

Edited by Mathieu Segers and Yoeri Albrecht 
Cover photo: Jörg Brüggeman/OSTKREUZ

Cover design: Van Lennep, Amsterdam

Lay-out: Crius Group, Hulshout

Amsterdam University Press English-language titles are distributed in the US and Canada by the University of Chicago Press.

ISBN $\quad 9789462983151$

e-ISBN $\quad 9789048533077$ (pdf)

e-ISBN $\quad 9789048533084$ (ePub)

NUR $\quad 320 / 740$

(C) M. Segers and Y. Albrecht / Amsterdam University Press B.V., Amsterdam 2016

All rights reserved. Without limiting the rights under copyright reserved above, no part of this book may be reproduced, stored in or introduced into a retrieval system, or transmitted, in any form or by any means (electronic, mechanical, photocopying, recording or otherwise) without the written permission of both the copyright owner and the author of the book.

Every effort has been made to obtain permission to use all copyrighted illustrations reproduced in this book. Nonetheless, whosoever believes to have rights to this material is advised to contact the publisher. 


\section{Contents}

Preface: Re-creating Europe $\quad 9$

Yoeri Albrecht

Introduction

13

Mathieu Segers

European Unity and its Vicissitudes (1959)

37

Isaiah Berlin

\section{Contemporary essays}

Homogeinity and Diversity

Tom Holland

On the Identity of the West

Larry Siedentop

The Cowardly Lion in Quest of Peace

Stella Ghervas

Afterglow of a Dead World

Benno Barnard

Anatomy of Resentment

Ivan Krastev

Thinking Europe - No Future?

121

Philipp Blom

My EUtopia: Empathy in a Union of Others 
Culture and the EU's Struggle for Legitimacy

Claudia Sternberg

\section{Historical texts}

Thoughts on the Future (1943)

Jean Monnet

Extracts from a speech in the Main Auditorium of

Cologne University (1946)

Konrad Adenauer

Extracts from a press conference (1960)

Charles de Gaulle

The Tragedy of Central Europe (1984)

Milan Kundera

The Bruges Speech (1988)

Margaret Thatcher

Extracts from a speech in the European Parliament (1994) 227 Václav Havel

Extracts from a speech in the European Parliament (1995) 237 François Mitterrand

The Special Quality of Europe is Culture (2001)

György Konrád

The Europe of Melancholy (2006)

251

Tomasso Padoa-Schioppa

New Alliances and Recomposition Logic (2008) 273 Édouard Balladur 
Remarks to the Turkish Parliament (2009)

Barack Obama

Germany in and with and for Europe (2011) 293

Helmut Schmidt

Biographies

309 


\title{
Culture and the EU's Struggle for Legitimacy
}

\author{
Claudia Sternberg
}

Europe's current crises seem to have true potential of splitting the Union apart. The Euro crisis, the looming threat of Brexit, and the refugee crisis have put the legitimacy of the EU and the integration project into serious question in the eyes of many. The EU's multiple crisis has once again shifted the question to the fore of why we are in this together to begin with. What are the ideas, commonalities, and aspirations that unite us? What differences divide us, are they dooming integration to failure, and do they have to be divisive? Might shared ideas, values, and goals help in overcoming Europe's present discontents, or is all lost in the face of clashing interests and incompatible identities? What role might culture play in this?

It is important to see today's crisis of EU legitimacy in historical context. This is what I will try to do in this essay, moving from the foundation of the European Communities in the 1950s to Europe's present discontents. I shall tell a story of how our ideas and standards of what it would mean for the EU to be legitimate have evolved over time - and of the roles that culture has played in these ideas. My story is a tale of how the European institutions, political leaders, opinion-making elites (what I shall refer to as "EU official" discourses) and the wider public in the members states fought over what the point of integration was, what form it should take - and on what grounds it could be claimed to be legitimate. I trace processes of meaning making, by which some ideas become more important than others in how we make sense of the EU and its legitimacy. Culture has played key parts in various of these competing ideas around EU legitimacy, not least in many claims that the Europeans form a community, and not only because they share a joint project, ${ }^{1}$ but also because 
they share common values and ideological commitments - and that, therefore, integration and a common European polity are justifiable.

My underlying philosophical notion of legitimacy is that something is legitimate not to the extent that it meets some abstract ideal criteria, nor to the extent that people believe that it is - but rather to the extent that it can be justified in terms of their beliefs about what constitutes legitimacy, in terms of what seems plausible to them. ${ }^{2}$ But what are people's beliefs about legitimacy? They change over time, are essentially contested, and embedded in deeper cultural, ideological, or cognitive conditions that circumscribe what it is plausible to say in a given context.

\section{A Discursive History of Struggles over EU Legitimacy}

A central discursive foundational legitimation technique of the 1950s, but still robust today, was to focus on common grounds, and gloss over potentially contentious issues. Central in this discursive culture of depoliticisation was the storyline that European integration was the only way to secure peace and prosperity across Europe. In this picture, integration was indispensable to achieving security, economic stability, and improved living conditions for Europe in an increasingly interdependent world, and, given the absolute necessity of securing these aims, a matter of no alternative as such. Note how this line of argument projected that there was such a thing as a European common interest, the lure of which belittled any clash of ideas regarding what it may consist in, or any disagreements over how to pursue it and how to distribute costs and benefits of doing so. A related narrative was that that everyone agreed on this European "common good", and what it consisted in. Cultural or ideological differences had no particular place in these discourses. Another technique of placing certain rules, actions, and institutional features beyond contestation appealed to "the law", and the constitutionalisation of Community law, as a source of legitimacy 
for the Communities. More fundamentally though, these peace and prosperity, indispensability, and common good storylines were underpinned by a general emphasis on harmony and agreement on universally shared goals. This rested on a discourse of hope, progress, and rising above circumstance, not least through enlightened planning and expert knowledge.

Notwithstanding, and counter to all harmonising efforts, rivalling ideas and understandings did exist, and were gathering force. The 196os and 1970s were marked not least by demands for European elections, first held in 1979. This campaign actively politicised what the Communities should be doing, and how they should be doing it. The stakes of integration, was the rallying cry, were "too important" to be decided on without the people. Rather, demands for European elections insisted on democracy as a condition of the Communities' legitimacy, reflecting a deeper cultural shift in hegemonic legitimacy understandings. Immediately after the Second World War, it had not been so clear that democracy was what rendered the post-war regimes of Europe legitimate in the eyes of their populations. Given the experience of authoritarianism, many people's ideas on democracy were marked by a certain distrust in unobstructed mass politics. Only gradually, over the course of the 15 years following the Second World War, did democracy emerge as the key element of political legitimacy in post-war Western Europe. ${ }^{3}$

The disputes of the 196os over how supranational the Communities should be, culminating in the French boycott of Council meetings, dealt another deadly blow to the narrative that largely everyone agreed on what they should be doing and how. The oil crises of the 1970s, finally, entailed severe financial and economic turmoil. This, in turn, undermined any claim that the Communities were guaranteed to bring Europe prosperity. It also undercut arguments turning on efficient governance on the basis of expert rationalities, and on overcoming clashing ideas, interests, and identities through the provision of competent problem-solving that benefited everyone. 
To these existential challenges, the European Institutions responded with a turn to "the citizens", and a pledge to "listen to what they wanted" in their official legitimation discourses and strategies. This new paradigm was anchored even more firmly when, in the early 1980s, the "peace-and-prosperity" storyline came under even greater fire. East-West relations were fraught once again, and the economies were in recession once again. Now the European institutions started a concerted campaign, aimed at reimagining the European (Economic, Atomic Energy, and Coal and Steel) Communities, holistically, as a "People's Europe". This appealed to people no longer as "market citizens" or consumers of energy and security: but as culturally embedded human beings, and as political citizens ("Union citizens") who had rights (participation and protection rights) that were specific to the European Community. The idea was to make Europe present and tangible in their everyday lives: through symbols and material benefits, through actively forging a European identity, by solemn declaration as well as by multiplying budgets in the cultural and communication policies.

Appeals to culture (and that was European as well as diverse national or subnational cultures, all "united in diversity") made their grand entry to the landscape of arguments about EU legitimacy. People were to associate Europe with culture, and this culture with themselves. The Commission in particular promoted production, consumption, and collaboration across member states, in music, fine arts, popular culture, as well as the field of the information media. This was to "bring the peoples of Europe together", and make them get to know, identify, and sympathise with each other. An underlying hope was that citizens would come to associate the practices of both consuming and producing culture with Community Europe. The gradual transnational intertwining of cultural production and consumption was to make Europeans identify with each other, with "Europe", and with the European Community as generous patron of culture. 
Such legitimation efforts became all the more necessary as integration picked up speed towards the goal of completing the Single Market by 1992. And then came Maastricht. The Maastricht Treaty, in the early 1990s, was a watershed. Its difficult ratification changed the landscape of what could plausibly be claimed about EU legitimacy. Fierce popular and political resistance, combined with plummeting public support rates, caused commentators as well as politicians to declare the "permissive consensus" dead, whereby the public had supported European integration enough not to interfere, or was at least indifferent enough about it. It became impossible to maintain that the EU reflected what the Europeans wanted. It was widely agreed then, too, that the EU's legitimacy was in crisis, and in many ways this is the crisis that has lasted ever since.

The Maastricht debates in the member states turned centrally around Economic and Monetary Union, and around concerns for economic and price stability. Yet, these concerns tended to have deeper cultural foundations. The French, for instance, dreaded subjecting their monetary action range to an independent European Central Bank and to the reunited Germany, whereas the Germans feared for their beloved national currency, stylised as a symbol of German wealth, power, and national identity - basically all that was good about Germany - and all now threatened by the Euro. Another central point in the ratification debates was whether democracy was possible at all on a European scale. An important French discourse in particular confined the practice of democracy and citizenship, or simply "the political", to the nation state. And a prominent German critique questioned whether meaningful EU-wide democracy was conceivable at all, given the lack of a European demos or people.

Together, these discursive developments rebuffed not only the peace-and-prosperity promise, but also the official focus on the "human dimension" of the EU, the promotion of "European culture", the fledgling efforts at EU-wide identity building, and the introduction of Union citizenship. In discursively managing the Maastricht crisis and the EU's ensuing general legitimacy 
crisis, the European institutions framed the EU's legitimacy gap almost exclusively in term of its "democratic deficit". This did take up national wider public critiques of EU democracy. But official rhetoric focused so much on this issue that it shifted much more urgent public concerns with the monetary union, or with the power balance in post-cold war Europe, to the background. About the Euro, one communication strategy was silence.

In addition, official discursive usage effectively stretched the meaning of "democracy" in three ways. During and immediately after the ratification crisis, it often equated democracy with transparency or openness, and "closeness to the citizens" with subsidiarity. In the medium term, the paradigm of governance claimed to offer (Romano Prodi) a more "genuine" and "authentic" alternative to traditional representative democracy, with which citizens had anyway become increasingly disillusioned. "Governance" focused attention on the consultation of civil society organisations as opposed to individual citizens or "the people". It prioritised responsiveness to citizen expectations over democratic control, representation, or accountability. Finally, institutional discourses and policies projected Union citizenship, and identity building, as solutions to the EU's democratic deficit.

If there wasn't a European demos, the challenge was to forge one, complete with constitutional patriotism. These discourses, policies, and reform attempts culminated in the project of the EU "constitution". The very name of the constitutional convention, and the eventual constitutional draft treaty was emblematic of the fact that the onus had now shifted, from a focus on culture and deliberate identity making of the essentialist kind, to the instigation of a constitutional "We, the people(s)" moment. The subsequent fate of these attempts is well known.

Perhaps at the end of the day, the official emphasis on democracy of the 1990 s and early 2000 s backfired. In national debates on the constitutional treaty, for example, democracy did play a key role - but not in the senses advanced by official rhetoric. Across the member states, the reading was pervasive that citizens resisted the EU constitution so as finally to throw a spanner into 
the works of the integration process - which otherwise would continue to proceed entirely beyond their influence or control. The French No-vote, in particular, was a statement of popular sovereignty - in a rather traditional, majoritarian-electoral sense of democracy. ${ }^{4}$ In other words, the innovative ways in which official discourses had employed terms like citizenship or democracy had failed to turn around the member state's public spheres - they held on to French national-republican tendencies, or the traditional democratic ideals implicit in British or German EU-democracy critiques. Even more importantly perhaps, the constitutional debates constituted powerful assertions of the will of the peoples to influence their country's future, and Europe's future.

The Euro crisis and the national debt crises in a number of member states, or now the current Brexit debate, have brought this message home with even greater urgency. Greek or Spanish resistance to externally imposed austerity measures, or the refugee crisis and the way in which the EU and Europe's leaders have addressed it, have seen forceful assertions not only of a popular will to be involved in the will formation about what is to be done. Even more importantly, on all these occasions it is now there for all to see how widely visions diverged of what was to be done, and of the social and economic future of Europe and its individual member states' social and economic future. Everywhere, citizens have been reclaiming their say in determining how politics is to relate to political, social, and economic realities. The people are forcing their way in once again. The old mantras of leaving it to the experts, or conjurations of an uncontroversial common European good, today do nothing less than discredit the EU's legitimacy.

\section{Three Structural Tensions}

What lessons, then, might we take away from this quick discursive-cultural history of struggles over EU legitimacy? Essentially, it was characterised by three structural tensions 
that run through all legitimation and delegitimation patterns mentioned so far.

First, they all involved a balancing act between bringing the people in and keeping them out. Ever since the late 1970s, official EU rhetoric turned on "what the people wanted". Yet, the fact that they revolved centrally around the European citizens and their needs and sensitivities did not necessarily mean that these citizens got more of an actual say. Really they remained objects, spectators, and addressees, rather than authors, of EU action. Yes, the will of the people was at the epicentre of these discourses. But it had a double status: it was referred to both as an independent source of legitimacy and, at the same time, an object of manipulation. Culture and the media were, at least partly, instruments of such manipulation as well as justifications in the related discourses. Giving the citizens what they wanted, in many official discourses pre- and post-Maastricht, remained a matter of efficient policy-making - only now this was framed in terms of citizen expectations. It was a matter of greater sophistication in mapping, as well as tweaking, citizens' expectations: in other words, of bringing them closer to the EU, rather than the EU closer to them. Bringing Europeans closer to each other, not least through cultural means, was a key tool in this approximation.

Of course, the tension between bringing the people in and keeping them out was built into the very nature of the European integration project. It arose from its being a top-down enterprise in engineering political reality - at the same time as needing to make plausible that it was somehow in line with "the will of the people" - both in order credibly to claim legitimacy and in order to actually function.

Secondly, the history of contests over EU legitimacy has been a tightrope walk between claiming legitimacy on the grounds of arguments about democracy and about efficient problem solving. My story shows that, rather than being mutually exclusive (as in too many cooks spoiling the broth), the two types of arguments have always, and necessarily, gone together. 
Not just any efficient performance output will do to enhance legitimacy - it has to have some credible claim of reflecting the will of the people. In addition, the credibility of such claims relies not on a simple match between citizen preferences and the goals of integration or its policies. Rather, it calls for open processes of contestation over what we want to achieve with it and what standards we want to measure it by. ${ }^{5}$ This is why the present disagreements and discontents may end up being a good thing for EU legitimacy on some level. Let me explain what I mean by this, by moving on to the third tension defining the struggle for EU legitimacy as I described it.

Thirdly and finally, the discursive history of EU legitimation can be told as a story of a push and pull between depoliticising forces and counter-forces that actively politicised the stakes of EU politics. It is a story of how it increasingly became undeniable that virtually any solution in integration politics creates winners and losers, of how any discourses glossing over this, and emphasising harmony, effectively became counter-productive. If there is one key lesson, it is that any claims about the EU's legitimacy have to openly acknowledge the essentially controversial nature of EU politics, in order to be plausible. This was a lesson to be drawn already from the constitutional affair, and the current debates around the Euro crisis drive the point home with even greater force. The EU studies literature has been observing politicisation as a phenomenon visible in public opinion data and electoral behaviour. While some have warned against opening Pandora's box and inviting contestation - on the grounds that it could then no longer be contained - other, normative accounts have advocated it, as an end in itself or as instrumental to creating, for example, a European public sphere. I would advocate being upfront about the controversial nature of everything that's at stake in EU politics is absolutely necessary in terms of what has a chance of being plausible, given the preceding discursive history of struggles over EU legitimacy. The good news is that this constant contestation can be a source of, and not only a threat to, EU legitimacy. How so? 


\section{Contestation, EU Politics as Play, and Mutual Recognition}

One could think of EU politics in terms of the metaphor of a game - and cultural production, exchange and consumption can play a role in probing and promoting this. Resting the political bond that ties us together on such an activity of play is less demanding than basing it on cultural or linguistic commonalities, or even on a "community of project". If we play a game together, we don't have to be alike, we don't have to like each other, or want the same thing - all we need to want to do is play the game against one another, and stick to a certain set of rules. Given the politicisation of EU politics that I sketched above, agreeing to contest or compete with each other might be all that the Europeans are willing to agree on - and it would not be little. While the legitimacy of the EU cannot thrive on contestation alone, it cannot thrive without contestation.

Play, and the "play-element in culture", can have civilising functions. It channels interactions into an activity with distinct rules, codes of behaviour, and clearly marked limits of where the game begins and ends. ${ }^{6}$ It teaches us how to lose, to be wrong, and to respect the other. ${ }^{7}$ Thinking of politics, and EU politics in particular, as a game, might, like a "well-functioning democracy" built on the "vibrant clash of democratic positions", be a way of trans- forming antagonism, or struggle between enemies, into agonism, or the struggle between adversaries. It might help to avoid the danger of "[t]oo much emphasis on consensus and the refusal of confrontation", which in turn may lead to citizen apathy, disaffection with political participation, or with European integration and EU politics or, worse still, "the crystallization of collective passions around issues which cannot be managed by the democratic process". ${ }^{8}$ Of course, the question remains why we should want to continue playing together. With the threat of parts of the Union breaking apart as tangible as never before, this is a serious question. Simply having locked ourselves into institutions and a whole system designed precisely to intertwine our European 
fates so much that cooperation has become the only option, seems to be working less well than it used to. More than ever, then, this situation calls for persuasive narratives, arguments, and images for why there should be European integration to begin with. And no such pleads will appear plausible today if they do not acknowledge our essential clashes of interest and identities.

Embracing confrontation and difference points to the centrality of a norm, practice, or aspiration around which the Europeans have built their Union over the past sixty years; that of mutual recognition. Besides being a philosophical concept, and a diplomatic, legal or technical norm, mutual recognition is also a state of mind, a daily practice, or an ethos. Mutual recognition as an ethos involves accepting to live and interact with each other's differences, without either trying to make the other side be like oneself, or simply stopping at the fact of difference and withdrawing into separate spaces. ${ }^{9}$ Supporting this aspiration may be one of the most important challenges, and roles, for culture in helping Europe overcome its present discontents, and threats of disintegration.

That the EU, an entirely new kind of political animal, was built around the aspiration of mutual recognition is no small miracle. For, at the same time, the propensity for denying each other this recognition remains imprinted in the Europeans' DNA. A tension between promises and denials of recognition is built into the European project, as it is innate to human nature. The refugee crisis, the Euro crisis, and perhaps even the Brexit debate, have cast a merciless light on this basic tension. Any apparent progress towards mutual recognition that we had witnessed in the last decades has seemed to move into reverse gear. Or at least it is radically tested. Longstanding but dormant clashes of interests and identities are festering back to the surface, touching some raw collective nerves in the process, reviving old tropes of prejudice and othering.

Europe's ongoing crises are manifestations that we are in a moment of renegotiation of who we are, and how we relate to each other. They have forced us to ask why and up to what 
point we want to stick together in Europe. Once more, we as Europeans, Germans, Greeks, Hungarians, Brits and all the rest, are recalibrating how far and under what conditions we recognise each other, and under what conditions our Union is to last. We are renegotiating the acceptable balance between interference in each other's affairs and deference to each other's ways of doing things and of being: we are engaged in managing the rules of recognition in Europe. One can think of this process as the deeper socio-cultural foundation of managing the political economy of monetary union, and of political union to the extent that it exists. Artists, thinkers, and producers as well as consumers of ideas and culture are called upon in reshaping this socio-cultural foundation in critical ways.

\section{Notes}

1. Kalypso Nicolaïdis, 'Kir Forever? The Journey of a Political Scientist in the Landscape of Mutual Recognition', The past and future of EU law : the classics of EU law revisited on the 5oth anniversary of the Rome Treaty (2010): pp. 447-455.

2. Claudia Sternberg, The Struggle for EU Legitimacy: Public Contestation, 1950-2005 (Basingstoke: Palgrave, 2013); D. Beetham, The Legitimation of Power. 2nd Edition. (Basingstoke: Palgrave Macmillan, 2013).

3. Sternberg, The Struggle for EU Legitimacy: Public Contestation, 1950-2005 (2013), 46; M. Conway and P. Romijn, 'Introduction to Theme Issue: Political Legitimacy in Mid-Twentieth Century Europe', Contemporary European History 13(04) (2004): 377-388; 380; M. Conway and V. Depkat, 'Towards a European History of the Discourse of Democracy: Discussing Democracy in Western Europe 1945-6o', in: M. Conway and K. K. Patel, Europeanization in the Twentieth Century: Historical Approaches (Basingstoke and New York: Palgrave Macmillan, 2010), 132-156.

4. Claudia Sternberg, 'Political legitimacy between democracy and effectiveness: trade-offs, interdependencies, and discursive constructions by the EU institutions', European Political Science Review 7(4) (2015a): pp. 615-638. 
5. Claudia Sternberg, 'What were the French telling us by voting down the "EU constitution"? A case for interpretive research on referendum debates', Comparative European Politics: 1-26 (2015b).

6. J. Huizinga, Homo Ludens. A Study of the Play-Element in Culture (Abingdon: Routledge, [1949] 2000), p.50.

7. H.G-. Gadamer, Das Erbe Europas: Beiträge (Frankfurt am Main: Suhrkamp, 1989), p.30.

8. C. Mouffe, The Democratic Paradox (London, New York: Verso, 2000), pp. 102-4.

9. Kalypso Nicolaïdis, 'Trusting the Poles? Constructing Europe through Mutual Recognition', Journal of European Public Policy 14(5) (2007): pp. 682-698; Kalypso Nicolaïdis, 'Kir Forever? The Journey of a Political Scientist in the Landscape of Mutual Recognition', The past and future of EU law : the classics of EU law revisited on the 5oth anniversary of the Rome Treaty (2010): pp. 447-455. K. Gartzou-Katsouyanni, Kalypso Nicolaïdis, and Claudia Sternberg, 'La crise de la zone euro et le déni de l'autre', in Pour une reconstruction de la reconnaissance mutuelle. Euro, les années critiques. E. Monnet and Claudia Sternberg (Paris: Presses Universitaires de France, 2015). 